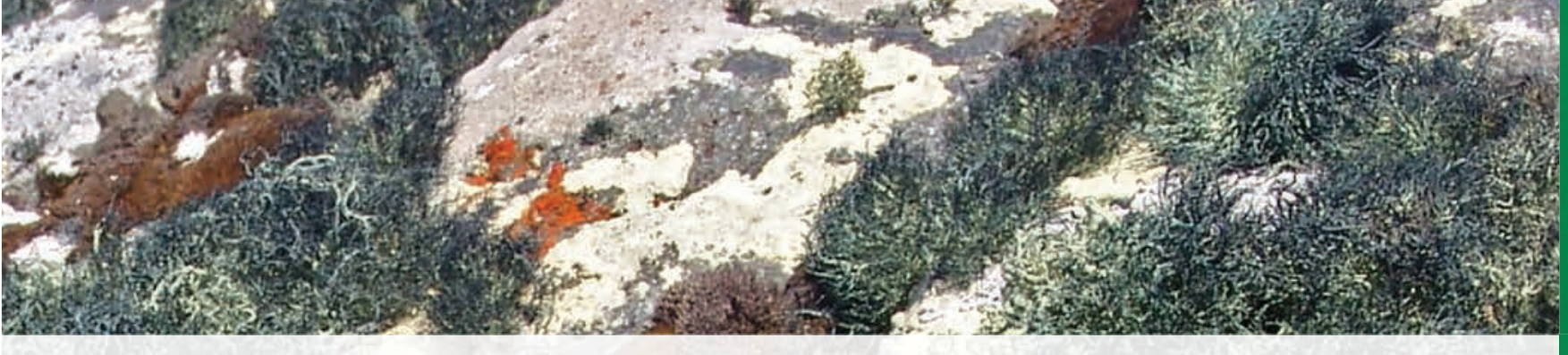

\title{
ARSENIC AND HEAVY METALS IN SOILS FROM "COMANDANTE FERRAZ" ANTARCTIC STATION (KING GEORGE ISLAND) AFTER FIRE
}

\author{
Tailisi Hoppe Trevizani*, Charles Roberto de Almeida Silva', Alessandra Pereira Majer ${ }^{2}$, \\ Andreza Portella Ribeiro ${ }^{3}$, Paulo Alves de Lima Ferreira', Rosalinda Carmela Montone ${ }^{1}$, \\ Rubens Cesar Lopes Figueira'. \\ 1'Instituto Oceanográfico da Universidade de São Paulo. Praça do Oceanográfico, 191, CEP 05508-120, São Paulo, Brazil. \\ ${ }^{2}$ Faculdade Estácio EUROPAN. Howard Archibal Acheson Junior, 393, CEP 06711-280, Cotia, SP, Brazil. \\ ${ }^{3}$ Universidade Nove de Julho. Francisco Matarazzo, 612, CEP 05001-100, São Paulo, Brazil. \\ *email: tailisi@usp.com
}

https://doi.org/10.4322/apa.2016.008

\begin{abstract}
The levels of arsenic and heavy metals were determined in soils collected in the surroundings of "Comandante Ferraz" Brazilian Antarctic Station, after a fire occurred in February 2012, to assess the environmental impacts in the area. Considering the elements evaluated, the ranges of concentrations in $\mathrm{mg} \mathrm{kg}^{-1}$ were as follows: arsenic, 2 to 8; cadmium, 1 to 7; chrome, 4 to 113; copper, 38 to 131; nickel, 3 to 11; lead, 3 to 328; and zinc, 41 to 263. The results were compared with those of previous assessments performed in soil and marine sediments collected near the Brazilian Station. Except for As, the data indicated (i) an increase in heavy metal contents; (ii) the need for remediation and (iii) more detailed studies on the contamination of the area after the accident and its effects on the biota.
\end{abstract}

Keywords: Metals, Spatial Distribution, Antarctic

\section{Introduction}

Antarctica is the Earth's continent least affected by the anthropogenic activities. Thus, this region has been considered an ideal observatory for research on the environmental impacts caused by humans. In contrast, the Polar Regions are vulnerable to contamination by pollution transported by atmospheric circulation and ocean currents. Furthermore, in Antarctica, a more direct exposure to these contaminants may occur in areas that have been continuously occupied by research stations for over fifty years (Vodopivez et al., 2001).

King George Island presents the highest potential for being affected by human activities, considering that it houses eight research stations. Admiralty Bay is located on the southeast coast of the island, which is considered part of the Antarctic Specially Managed Area (ASMA) region, where the impacts produced by different countries should be minimized. Since 1984, three research stations, including
"Comandante Ferraz" Antarctic Station (EACF) have been operating in this area (Montone et al., 2001; Ribeiro et al., 2011).

An unexpected increase in contamination on King George Island may have occurred after the fire accident at EACF on February 25, 2012. In this tragic event, an explosion in the engine room destroyed the research laboratories, other facilities, and personal belongings. Unfortunately, besides the material damages, which represented about $70 \%$ of the permanent settlement, there were also losses of human lives - two military officers that belonged to the Antarctic Marine Base Group (Guerra et al., 2013; Colabuono et al., 2015).

Many substances may have been released onto the area contiguous to the EACF, which could have caused increased levels of chemical contaminants. Therefore, this study was conducted to support the monitoring activities related to the 
evaluation of arsenic and heavy metal contents in the soil close to the area where the station was located.

\section{Materials and Methods}

Sampling was conducted in Admiralty Bay, in the area adjacent to EACF, during the $31^{\text {st }}$ Brazilian Antarctic Expedition between December 2012 and February 2013 (Figure 1A). Sampling depth ranged from 0 to $5 \mathrm{~cm}$, considering that most metals accumulate in the soil surface. A polyethylene tube of $4 \mathrm{~cm}$ in diameter was used to collect 25 soil samples, which were stored in a clean container at $-20{ }^{\circ} \mathrm{C}$. After that, the samples were lyophilized, homogenized, and stored in polyethylene bags until chemical analysis.

The method 3050A (U.S EPA, 1996), which is based on a blend of acids, was used to digest the soils. Optical Emission Spectrometry with Inductively Coupled Plasma (ICP-OES) was used to determine Arsenic (As), Cadmium (Cd), Chromium (Cr), Copper (Cu), Nickel (Ni), Lead (Pb), and $\mathrm{Zinc}(\mathrm{Zn})$ contents in the soil samples.

\section{Results}

The results obtained approximately one year after the fire accident are presented in Table 1, together with Resolution 420 of the National Environmental Council guiding values for soils (CONAMA, 2009), as well as the levels observed in previous studies conducted in Ferraz Station (Ribeiro et al., 2011; Santos et al., 2005). CONAMA Resolution 420/2009 defines the principal ranges of chemical concentrations, i.e., (i) Prevention Values (PV) indicate the upper limit below which the principal soil functions are sustained and (ii) Research Values (RV) are the concentration levels above which there are direct or indirect potential risks for human health. Accordingly, CONAMA targets can also be considered as guideline values to evaluate the risk to the Antarctic biota because of inorganic compounds released to the environment after the fire accident. Figure 1B also shows the levels observed for the elements studied in the soils collected close to EACF.

\section{Discussion}

Comparison of the concentrations estimated in this study with the PV and RV established by CONAMA (Table 1) shows that As and Ni were below those of PV (15 and $30 \mathrm{mg} \cdot \mathrm{kg}^{-1}$, respectively), demonstrating that there is no local enrichment by these elements in the analyzed soil. Zn presented higher concentration values, but also below PV for soils (300 mg. $\left.\mathrm{kg}^{-1}\right)$. However, the concentration of $\mathrm{Cd}, \mathrm{Cr}$, and $\mathrm{Cu}$ exceeded PV (1.3 mg. $\mathrm{kg}^{-1}, 75 \mathrm{mg} \cdot \mathrm{kg}^{-1}$ and $60 \mathrm{mg} \cdot \mathrm{kg}^{-1}$, respectively), as well as those of $\mathrm{Pb}$, which exceeded by more than $9 \%$ the $300 \mathrm{mg} \cdot \mathrm{kg}^{-1}$ established in $\mathrm{RV}$, suggesting the soil contamination by these elements,

Table 1. Mean and concentration range $\left(\mathrm{mg}_{\mathrm{kg}} \mathrm{kg}^{-1}\right)$ obtained for metals and arsenic in soil from the surroundings of EACF, compared with those of previous works and CONAMA Guidelines Values.

\begin{tabular}{|c|c|c|c|c|c|c|c|}
\hline Site & As & Cd & Cr & Cu & $\mathbf{N i}$ & $\mathbf{P b}$ & Zn \\
\hline \multirow[t]{2}{*}{ Ferraz Station ${ }^{b}$} & 7 & 0.7 & 10 & 67 & 5.6 & 5.3 & 65 \\
\hline & $2-11$ & $0.6-0.9$ & $9-12$ & $60-71$ & $4-7$ & $4-6$ & $58-63$ \\
\hline$P V^{d}$ & 15 & 1.3 & 75 & 60 & 30 & 72 & 300 \\
\hline$R V^{d}$ & 55 & 8 & 300 & 400 & 100 & 300 & 1000 \\
\hline
\end{tabular}

a Present study. Matrix: Soil. Sampled during the 2012/ 2013 austral summer

Ribeiro et al., 2011. Matrix: marine sediments. Sampled during the 2006/ 2007 austral summer.

' Santos et al., 2005. Matrix: Soil. Sampled during the 2002/ 2003 austral summer.

CONAMA, 2009. 

especially by $\mathrm{Pb}$ (CONAMA, 2009). Based on this criterion, the heavy metal enrichment may represent potential toxicity to the Antarctic biota

Furthermore, comparison between our results and those obtained by previous assessments of marine sediments and soil of the surroundings of EACF (Table 1) showed that As was the only element whose concentration did not increase. Notwithstanding, a slight increase in the mean level of $\mathrm{Cd}$ and $\mathrm{Ni}$ was noticed in the current samples. Cr presented an increase of $72 \%$ compared with the sediment analyzed in 2011, but this occurred only in the region where the power generators were located at EACF. The contents of $\mathrm{Cu}$ and $\mathrm{Zn}$ augmented by $29 \%$ and $22 \%$, respectively, compared with the results obtained by Ribeiro et al., 2011.

Likewise, as highlighted by Guerra et al. (2013), Pb levels require more concern and research, considering that the level of this metal had an increase of $300 \%$ compared with that reported by Santos et al. (2005), and of $128 \%$ compared with the data presented by Ribeiro et al. (2011). Contamination with $\mathrm{Pb}$ is precisely located where the reactors and research equipment composed of $\mathrm{Pb}$ alloy were stored at EACF (Ribeiro et al., 2011).

As a consequence of the accident, the increased levels found for the studied elements, especially for $\mathrm{Pb}$, in the soil surrounding the EACF may be associated with the burning fuels; the composition of the painting used in the former station; and the battery bank, alloys, and various laboratory reagents, which belonged to the part of the structure or were used at the EACF, that were eventually absorbed by the environment because of the fire.

\section{Conclusion}

The results of the present study provide an updated overview of the concentrations of heavy metals and arsenic in soil samples collected near EACF approximately one year after the fire accident that destroyed the main facilities of the station. In general, increased concentrations of $\mathrm{Cd}$, $\mathrm{Cr}, \mathrm{Cu}, \mathrm{Ni}, \mathrm{Pb}$ and $\mathrm{Zn}$ were observed when compared with literature values, considered as background levels. As the concentrations of $\mathrm{Cd}, \mathrm{Cr}$, and $\mathrm{Cu}$ exceed the value of prevention established by the Brazilian legislation and the levels of $\mathrm{Pb}$ exceed the value of research that indicates the need for remediation and more detailed studies on the contamination of the vicinities of EACF, this contamination can affect the biota in the Admiralty Bay region.

\section{Acknowledgements}

This work Integrates the National Institute of Science and Technology Antarctic Environmental Research (INCTAPA) that receives scientific and financial support from the National Council for Research and Development (CNPq Process no. 574018/2008-5) and Carlos Chagas Research Support Foundation of the State of Rio de Janeiro (FAPERJ no. E-16/170.023/2008). The authors also acknowledge the support of the Brazilian Ministries of Science, Technology and Innovation (MCTI), Environment (MMA), and InterMinistry Commission for Sea Resources (CIRM).

\section{References}

Colabuono, F. I., Taniguchi, S., Cipro, C. V. Z., Silva, J., Bícego, M. C., \& Montone, R. C. (2015). Persistent organic pollutants and polycyclic aromatic hydrocarbons in mosses after fire at the Brazilian Antarctic Station. Marine Pollution Bulletin, 93(1), 266-269

Conselho Nacional do Meio Ambiente - CONAMA. Resolução $n^{\circ} 420.2009$.

Guerra, M. B. B., Neto, E. L., Prianti, M. T. A., Pereira-Filho, E. R., \& Schaefer, C. E. G. R. (2013). Post-fire study of the Brazilian Scientific Antarctic Station: toxic element contamination and potential mobility on the surrounding environment. Microchemical Journal, 110, 21-27.

Montone, R. C., Taniguchi, S., \& Weber, R. R. (2001). Polychorinated biphenyls in marine sediments of Admiralty Bay, King George Island. Antarctica. Marine Pollution Bulletin, 42, 611-614.

Ribeiro, A. P., Figueira, R. C. L., Martins, C. C., Silva, C. R. A., França, E. J., Bícego, M. C., Mahiques, M. M., \& Montone, R. C. (2011). Arsenic and trace metal contents in sediment profiles from the Admiralty Bay, King George Island, Antarctica. Marine Pollution Bulletin, 62, 192-196. 


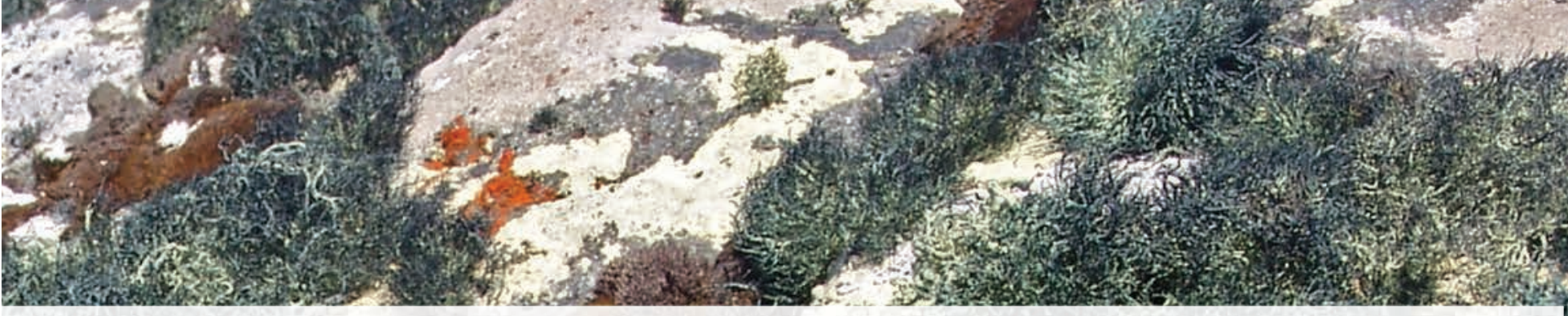

Santos, I. R., Silva-Filho, E. V., Schaefer, C. E., Albuquerque Filho, M. R., \& Campos, L. S. (2005). Heavy metals contamination in coastal sediments and soils near the Brazilian Antarctic Station, King George Island. Marine Pollution Bulletin, 50, $185-194$.

United States Environmental Protection Agency - U.S. EPA. Method 3050B: acid digestion of sediments, sludges and soil. Revision 2. December, 1996.

Vodopivez, C., Smichowski, P., \& Marcovecchio, J. (2001). Trace metals monitoring as a tool for characterization of Antarctic ecosystems and environmental management. The Argentine programme at Jubany Station. In S. Caroli, P. Cescon \& D. W. H. Walton. Environmental Contamination in Antarctica: a challenge to analytical chemistry. Elsevier. $406 \mathrm{p}$. 